\title{
Vitamin D reseptör gen polimorfizmi ile primer biliyer siroz ilişkisi
}

\author{
Genetic association of vitamin D receptor polymorphisms with primary biliary cirrhosis
}

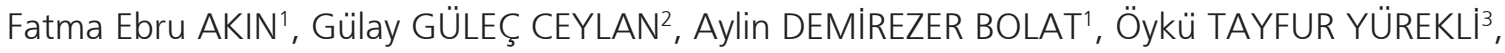 \\ Mustafa TAHTACI ${ }^{3}$, Eyüp SELVi' ${ }^{1}$, Naciye Şemnur BÜYÜKAŞIK ${ }^{1}$, Osman ERSOY ${ }^{3}$ \\ Atatürk Eğitim ve Araştırma Hastanesi, ' Gastroenteroloji Kliniği, Ankara \\ Yıldırım Beyazıt Üniversitesi Tıp Fakültesi, ${ }^{2}$ Tıbbi Genetik Bilim Dalı, ${ }^{3}$ Gastroenteroloji Bilim Dalı, Ankara
}

\begin{abstract}
Giriş ve Amaç: Primer biliyer siroz, kronik kolestatik otoimmün karaciğer hastalığıdır. Primer biliyer sirozun patogenezinde genetik faktörler rol oynamaktadır. 1,25-dihidroksivitamin D3 (1,25(OH)2D3), sekosteroid hormondur. 1,25(OH)2D3 etkilerini vitamin D reseptör aracılığı ile gösterir. Vitamin $D$ reseptör geninde birkaç polimorfizm bildirilmişdir. Bazı otoimmün hastalıklar vitamin D reseptör gen polimorfizmi ile ilişkili bulunmuştur. Biz bu çalışmada primer biliyer siroz ile vitamin D reseptör gen polimorfizminin ilişkisini değerlendirdik. Gereç ve Yöntem: Atatürk Eğitim ve Araştırma Hastanesi Gastoenteroloji Kliniği'nde, 20072012 yılları arasında primer biliyer siroz tanısı ile takip edilmekte olan hastalar alındı. Çalışmaya 16 primer biliyer siroz ve 28 sağıkı gönüllü dahil edildi. Biliyer obstrüksiyon varlığı görüntüleme yöntemleri ile ekarte edildi. 16 hastanın 13'ünde karaciğer biyopsisi vardı ve primer biliyer siroz ile uyumlu idi. Eşlik eden başka karaciğer hastalığı yoktu. Vitamin D reseptör genotiplendirilmesi; Bsml, Apal, Taql endonükleazları kullanılarak polimerize zincir reaksiyonu-restriksiyon parçacık uzunluk polmorfizmi ile yapıldı. Bulgular: Hastaların 14'ü kadın, 2'si erkekti.

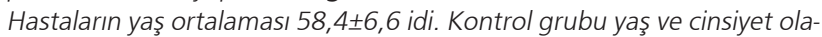
rak denkti. Vitamin D reseptör gen Bsml, Apal, Taql polimorfizmlerinin primer biliyer siroz ve konrol grubunda farklı olmadığı görüldü. Sonuç: Biz bu çalışmada, primer biliyer siroz ile vitamin D reseptör gen Bsml, Apal, Taql polimorfizmleri arasında ilişki saptamadık.
\end{abstract}

Anahtar kelimeler: Polimorfizm, primer biliyer siroz, vitamin D reseptör

\section{Giris}

Primer biliyer siroz (PBS), ilerleyici portal lenfositik infiltrasyon ve intrahepatik safra kanalı epitel hücrelerinin harabiyeti ile seyreden otoimmün, kolestatik karaciğer hastalığıdır. Karaciğer fibrozisi ve siroz ile sonuçlanabilmektedir (1). PBS'nin etiyolojisinde genetik ve çevresel faktörler önemli rol oynamaktadır (2). PBS'den etkilenen hastaların aile bireylerinde ve monozigot ikizlerde hastalık prevalansının genel popülasyondan daha yüksek olduğu görülmüştür (3). PBS'nin patogenezinde rol oynayan birçok gen ile ilgili çalışma mevcuttur. Örneğin, majör histokompatibilite kompleks (MHC) klass II polimorfizmi PBS'den koruyucu etkiye sahipken sitotoksik T lenfosit

\footnotetext{
Iletişim: Fatma Ebru AKIN

Atatürk Eğitim ve Araştırma Hastanesi, Gastroenteroloji Kliniği,

Bilkent, Ankara, Türkiye

Tel: +90 3122912525 • E-mail: ebrudakin@hotmail.com
}

Background and Aims: Primary biliary cirrhosis is a chronic cholestatic autoimmune liver disease. Genetic factors appear to be involved in the pathogenesis of primary biliary cirrhosis. 1,25 dihydroxyvitamin D3, is a secosteroid hormone that mediates its effects through the vitamin $D$ receptor. A few polymorphisms have been defined in the vitamin $D$ receptor gene so far. Autoimmune diseases have been found to be associated with vitamin D receptor gene polymorphisms. We evaluated the relationship between vitamin D receptor gene polymorphisms and primary biliary cirrhosis. Materials and Methods: Primary biliary cirrhosis patients who were treated in the Atatürk Research and Teaching Hospital Gastroenterology Department, from 2007-2012 are included. The study group included 16 primary biliary cirrhosis patients and 28 healthy people. Biliary obstruction was excluded using imaging modalities. Of the 16 patients, 13 had liver biopsies consistent with primary biliary cirrhosis. There were no concomitant liver diseases. Vitamin D receptor genotyping was done by the polymerase chain reaction-restriction fragment length polymorphism with Bsml, Apal, and Taql endonucleases. Results: Of the 16 patients, 14 were female. The average age was $58.4 \pm 6.6$ years. Control group patients were age- and gender-matched. No differences in vitamin D receptor gene Bsml, Apal, and Taql polymorphisms were found between the primary biliary cirrhosis and control groups. Conclusion: We did not find any relationship between vitamin D receptor gene Bsml, Apal, and Taql polymorphisms and primary biliary cirrhosis.

Key words: Polymorphisms, primary biliary cirrhosis, vitamin D receptor

antijen 4 (CTLA 4) ve interlökin-1 (IL-1) PBS gelişimi ve hastalık progresyonu ile ilişkili bulunmuştur (4).

1,25-dihidroksi vitamin D3 $\left[1,25(\mathrm{OH})_{2} \mathrm{D}_{3}\right]$ kalsiyum ve kemik metabolizmasında rol oynadığı iyi bilinmektedir ve son yılarda immünregülatuvar rolünün de olduğu gösterilmiştir (5). $1,25(\mathrm{OH})_{2} \mathrm{D}_{3}$ 'ün romatoid artrit, tip 1 diabet, multipl skleroz, inflamatuvar barsak hastalığı gibi çeşitli otoimmün durumlarda rol oynadığı görülmüştür (6). 1,25(OH) ${ }_{2} \mathrm{D}_{3}$ biyolojik etkilerini nükleer reseptör olan vitamin $\mathrm{D}$ reseptör (VDR)'ye bağlanarak göstermektedir (7). VDR geninde bazı polimorfizmler gösterilmiştir. Bunlardan rs1544410 (Bsml), 
rs7975232 (Apal) intron 8'de, rs731236 (Taql) ekson 9'da bulunmaktadır (8). PBS ile VDR polimorfizminin ilişkisini gösteren farklı etnik gruplardan çalışmalar yapılmıştır ve sonuçlar arasında çelişkiler mevcuttur (9-14).

Biz bu çalışmada PBS riski ile VDR polimorfizmi (Bsml, Apal, Taql) arasındaki ilişkiyi değerlendirdik.

\section{GEREÇ ve YÖNTEM}

Çalışmaya Ankara Atatürk Eğitim ve Araştırma Hastanesi Gastroenteroloji Kliniği'nde 2007-2012 yılları arasında PBS tanısı ile takip edilmekte olan 16 (14 kadın, 2 erkek) hasta

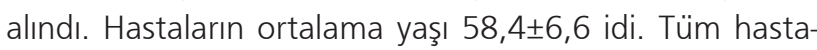
lar PBS tanısı için Avrupa Karaciğer Çalışmaları Derneği (EASL) kılavuzunun önerdiği kriterleri taşıyordu (15). Biyokimyasal olarak kolestaz varlığı [başlıca alkalen fosfataz (ALP) yüksekliği], anti mitokondrial antikor (AMA) pozitifliği, nonsüpüratif destrüktif kolanjit ve interlobular safra kanallarının destrüksiyonunun histolojik bulgularından 2'si pozitif olan hastalar PBS kabul edildi. Biliyer obstrüksiyon varlığı görüntüleme yöntemleri ile ekarte edildi.16 hastanın 13'ünde karaciğer biyopsisi vardı ve PBS ile uyumlu idi. Eşlik eden başka karaciğer hastalığı yoktu. Hastaların demografik özellikleri Tablo 1'de gösterildi.

Kontrol grubu olarak 28 sağlıklı gönüllüden kan alındı. Çalışmaya katılan her bir hastadan aydınlatılmış onam formu alındı. Çalışma protokolü için Yıldırım Beyazıt Üniversitesi Tıp Fakültesi Ilaç Dışı Klinik Araştırmalar Etik Kurulundan onay alındı. Genomik DNA, periferal mononükleer kan hücrelerinden QIAamp DNA Blood Mini Kit (Qiagen K.K., Tokyo, Japan) kullanılarak elde edildi. VDR genotiplendirilmesi; Bsml, Apal, Taql endonükleazları kullanılarak polimerize zincir reaksiyonu restriksiyon parçacık uzunluk polimorfizmi (PCR-RFLP) ile yapıldı.

İstatistik analizler SPSS 17 kullanılarak yapıldı. PBS ve kontrol grubu arasındaki genotip sıkıklarının analizi $\chi 2$ ve Fisher's exact test kullanılarak yapıldı. $P<0,05$ anlamlı kabul edildi.

\section{BULGULAR}

Biz bu çalışmada 16 PBS ve 28 sağlıklı gönüllüde intron 8'de 2 (rs1544410-Bsl; rs7975232-Apal) ve ekson 9'da 1 (rs731236=Taql) VDR gen polimorfizmini analiz ettik. PBS hastalarının yaş ortalaması 58.4 \pm 6.6 idi. Hastaların demografik özellikleri Tablo 1'de gösterildi. 14 hasta kadın, 2 hasta erkekdi. Hastaların serum alkalen fosfataz değerlerinin ortalaması $258 \pm 120 \mathrm{U} / \mathrm{L}$, gama glutamil transferaz (GGT) değerlerinin ortalaması 260. $\pm 262 \mathrm{U} / \mathrm{L}$ idi. Hastaların 15'inde AMA M2 pozitif iken, 1 hastada negatifti. PBS ve kontrol grubu arasında Bsml, Apal, Taql polimorfizminde allelik sıklıkların analizinde anlamlı fark bulmadık. Bsml, Apal ve Taql polimorfizmindeki allelik sıklıklar Tablo 2'de gösterildi.

\section{TARTIŞMA}

Biz bu çalışmada, Bsml, Apal, Taql VDR gen polimorfizmi ile PBS riski arasındaki ilişkiyi değerlendirdik. Bu çaışmamızda PBS riski ile Bsml, Apal, Taql arasında ilişki saptamadık. Literatüre baktığımızda PBS riski ve VDR gen polimorfizmi arasındaki ilişkiyi açıklamaya çalışan çalışmalarda farklı sonuçlar elde edilmiş olduğunu görmekteyiz (9-14). Vogel A ve ark.'nın Alman hastalar üzerinde

Tablo 1. Hastaların demograffk özellikleri ve laboratuvar bulguları

\section{PBS $(n=16)$}

Yaş

$58.4 \pm 6.6$

Cinsiyet (K/E)

$14 / 2$

AMA M2 (+/-)

$15 / 1$

$\operatorname{ALT}(U / L)$

$59 \pm 33.6$

$\operatorname{ALP}(U / L)$

$258 \pm 120$

GGT (U/L)

$260 . \pm 262$

Bilirübin (mg/dl)

$0.9 \pm 0.4$

Albümin ( $\mathrm{g} / \mathrm{dl}$ )

$4.3 \pm 0.4$

INR

$0.98 \pm 0.15$

Kolesterol (mg/dl)

$226 \pm 53$

Trigliserd (mg/dl)

$139 \pm 44$

Ca (mg/dl)

$9.6 \pm 0.6$

$\mathrm{P}$ (mg/dl)

$3.3 \pm 0.7$

Vitamin D

$10 \pm 3.1$

AMA: Antimitokondrial antikor, ALP: Alkalen fosfataz, GGT: Gama glutamil transferaz, INR: Uluslararası normalleştirilmiş oran, Ca: Kalsiyum, P: Fosfor

Tablo 2. Vitamin D reseptör polimorfizminin primer biliyer siroz ve kontrol grubunda dağilımı

\begin{tabular}{|c|c|c|c|}
\hline $\begin{array}{c}\text { Genotip } \\
(\mathbf{n = 1 6 )}\end{array}$ & $\begin{array}{c}\text { PBS (\%) } \\
(\mathbf{n = 2 8})\end{array}$ & Kontrol (\%) & $\mathbf{P}$ \\
\hline Bsml & & & \\
\hline $\mathrm{BB}$ & $2(\% 12.5)$ & $4(\% 14.5)$ & 0.624 \\
\hline $\mathrm{Bb}$ & $8(\% 50)$ & $11(\% 39.3)$ & 0.353 \\
\hline $\mathrm{bb}$ & $6(\% 37.5)$ & $13(\% 46.4)$ & 0.4 \\
\hline Apal & & & \\
\hline $\mathrm{AA}$ & $9(\% 56.2)$ & $13(\% 46.4)$ & 0.377 \\
\hline $\mathrm{Aa}$ & $5(\% 31.2)$ & $9(\% 32.1)$ & 0.612 \\
\hline $\mathrm{aa}$ & $2(\% 12.6)$ & $6(\% 21.5)$ & 0.38 \\
\hline Taql & & & \\
\hline $\mathrm{TT}$ & $8(\% 50)$ & $14(\% 50)$ & 0.623 \\
\hline $\mathrm{Tt}$ & $5(\% 31.2)$ & $9(\% 32.1)$ & 0.612 \\
\hline $\mathrm{Tt}$ & $3(\% 18.8)$ & $5(\% 17.9)$ & 0.620 \\
\hline
\end{tabular}


yaptığı çalışmada, PBS'li 74 hasta, 214 sağ ıkklı kontrol ile karşılaştırılmış. Bu çalışmada PBS riski ile Fokl, Apal, Taql ile ilişki saptanmazken PBS ile Bsml polimorfizmi arasında anlamlı ilişki bulunmuş (10). Macaristan'dan Lakatos LP ve ark.' larının çalışmasında PBS'li 33 hasta, 84 sağlıklı kontrol ile karşılaştııılmış. PBS'li hastalarda VDR, Bsml, BB genotipinin sıklığı daha yüksek bulunmuş (11).

Çin'den yapılan bir diğer çalışmada PBS'li 58 hasta, 160 sağlıkı kontrol ile karşılaştııımış. PBS riski ile Fokl, Apal, Taql polimorfizmi ile ilişki saptanmazken PBS riski ile Bsml polimorfizmi arasında anlamlı ilişki saptanmış (12). Tanaka ve ark.'nın yaptığı çok merkezli çalışmada ise PBS'si olan 195 Japon, 139 Italyan, 334 sağlıklı kontrol ile karşılaştıııımış. PBS riski ile Bsml, Apal, Taql polimorfizmleri arasındaki ilişki değerlendirilmiş. Bsml polimorfizminin BB genotipi ile PBS riski arasında anlamlı ilişki saptanmış. Subgrup analizi yapıldığında da Japonlarda ve Italyanlarda Bsml polimorfizmi ile PBS riski arasındaki ilişki anlamlı bulunmuş (13). Polonya'dan yapılan çalışmada PBS'li 143 hasta, 306 sağlıklı kontrolde Bsml, Apal, Taql polimorfizmleri çalışıımıs. PBS ile Apal ile ilişki saptanmazken PBS ile Bsml (b alleli) polimorfizmi ve Taql (t alleli) polimorfizmi arasında anlamlı ilişki saptanmış. Bsml ve Taql polimorfizmleri, tanı anında saptanan ileri fibroz ve siroz ile ilişkili bulunmuş (14).

PBS ile VDR gen polimorfizmi ile ilgili literatürde 3 metaanaliz yayınlanmış (16-18). Li YJ ve ark.'nın yazdığı metaanalizde 6 çalışmadan 1.322 PBS'li hasta ile 2.264 kontrol hastası değerlendirilmiş. Bu metaanalizde Taql polimorfizmi ile PBS riski anlamlı olarak ilişkili bulunmuş. Ancak Apal ve Bsml polimorfizmi ile PBS riski arasında ilişki saptanamamış (16). Mo C ve ark.'Iarının yaptığı metaanalize 6 çalışma dahil edilmiş ve Apal, Taql, Bsml polimorfizmi ile PBS riski toplam hasta sayısına göre ve etnisiteye göre değerlendirilmiş. Apal polimorfizmi ve PBS riski arasındaki ilişki 609 hasta ve 1.015 kontrolü içeren 4 raporda değerlendirilmiş. Apal polimorfizmi PBS riski ile ilişkili bulunmamış. Bsml polimorfizmi ve PBS riski arasındaki ilişkiyi belirlemek için 673 hasta ve 1.148 kontrol değerlendirilmiş. Genel popülasyonda ve etnisiteye göre subgrup analizi yapıldığında Bsml polimorfizmi ile PBS riski arasında ilişki bulunamamış. Taql polimorfizmi ve PBS riski arasındaki ilişki ise 609 hasta ve 1.015 kontrol üzerinde değerlendirilmiş. Taql polimorfizmi ve PBS riski arasında genel popülasyon ve etnisiteye göre subgrup analizinde ilişki saptanmamış (17). Bu metaanalizdeki bulgular bizim çaIsşmamızda elde ettiğimiz sonuçlar ile benzer görünmektedir. Bir başka metaanalizde ise 6 çalışmadan 672 hasta 1148 kontrol üzerinde PBS riski ve VDR polimorfizmi arasındaki ilişki değerlendirilmiş. Bu metaanalizde bütün hastaların değerlendirildiği genel analizde PBS riski ile VDR polimorfizmi arasında ilişki görülmemiş. Ancak subgrup analizi yapıldığında Asya subgrubunda Apal polimorfizminde anlamlı ilişki görülürken Kafkas subgrubunda Taql polimorfizmi ile PBS riski arasında ilişki saptanmış (18).

Bu sonuçlara bakıldığında VDR polimorfizminin PBS gelişiminde bağımsız rolü olmadığı bunun yerine diğer biyolojik ve çevresel faktörler ile birlikte kombine etkinin sözkonusu olabileceği düşünülmelidir. Bizim çalışmamızın bazı zayıf yönleri mevcuttu. Bu zayıf yönlerin en başında hasta sayımızın yetersiz olması geliyordu. Bir diğer zayıf tarafı VDR polimorfizmi ile PBS riski arasındaki ilişkinin moleküler mekanizması ayrıntılı olarak bilinmemektedir.

Bu çalışmada PBS riski ile VDR'nin Bsml, Apal ve Taql polimorfizmi arasında ilişki saptamadık. Bundan sonraki çalışmalar sadece PBS gelişiminde VDR polimorfizminin etkisi üzerine odaklanmamalı, aynı zamanda hastalığın gidişatı üzerine olan etkileri üzerinde de durulmalıdır.

\section{KAYNAKLAR}

1. Kaplan MM, Gershwin ME. Primary biliary cirrhosis. N Engl J Med 2005;353:1261-73.

2. Gershwin ME, Mackay IR. The causes of primary biliary cirrhosis: Convenient and inconvenient truths. Hepatology 2008;47:737-45.

3. Lazaridis KN, Juran BD, Boe GM, et al. Increased prevalence of antimitochondrial antibodies in first-degree relatives of patients with primary biliary cirrhosis. Hepatology 2007;46:785-92.

4. Chen RR, Han ZY, Li JG, et al. Cytotoxic T-lymphocyte antigen 4 gene $+49 A / G$ polymorphism significantly associated with susceptibility to primary biliary cirrhosis: a meta-analysis. J Dig Dis 2011;12:428-35.

5. Peelen $E$, Knippenberg $S$, Muris $A H$, et al. Effects of vitamin D on the peripheral adaptive immune system: a review. Autoimmun Rev 2011;10:733-43.

6. Souberbielle JC, Body JJ, Lappe JM, et al. Vitamin D and musculoskeletal health, cardiovascular disease, autoimmunity and cancer: Recommendations for clinical practice. Autoimmun Rev 2010;9:709-15

7. Norman AW. From vitamin D to hormone D: fundamentals of the vitamin $D$ endocrine system essential for good health. Am J Clin Nutr 2008;88:491S-499S.

8. Morrison NA, Qi JC, Tokita A, et al. Prediction of bone density from vitamin D receptor alleles. Nature 1994;367:284-7.

9 Halmos B, Szalay F, Cserniczky T, et al. Association of primary biliary cirrhosis with vitamin D receptor Bsml genotype polymorphism in a Hungarian population. Dig Dis Sci 2000;45:1091-5.

10. Vogel A, Strassburg CP, Manns MP. Genetic association of vitamin $D$ receptor polymorphisms with primary biliary cirrhosis and autoimmune hepatitis. Hepatology 2002;35:126-31. 
11. Lakatos $L P$, Bajnok $E$, Hegedus D. Vitamin D receptor, oestrogen receptor-alpha gene and interleukin-1 receptor antagonist gene polymorphisms in Hungarian patients with primary biliary cirrhosis. Eur J Gastroenterol Hepatol 2002;14:733-40.

12. Fan $L, T u X$, Zhu $Y$, et al. Genetic association of vitamin $D$ receptor polymorphisms with autoimmune hepatitis and primary biliary cirrhosis in the Chinese. J Gastroenterol Hepatol 2005;20:249-55.

13. Tanaka A, Nezu S, Uegaki $S$, et al. Vitamin D receptor polymorphisms are associated with increased susceptibility to primary biliary cirrhosis in Japanese and Italian populations. J Hepatol 2009;50:1202-9.

14. Kempińska-Podhorecka A, Wunsch E, Jarowicz T, et al. Vitamin D receptor polymorphisms predispose to primary biliary cirrhosis and severity of the disease in polish population. Gastroenterol Res Pract 2012;2012:408723.
15. European Association for the Study of the Liver. EASL Clinical Practice Guidelines: management of cholestatic liver diseases. J Hepatol 2009;51:237-67.

16. Li YJ, Tang YW, Shi YQ, et al. Polymorphisms in the vitamin D receptor gene and risk of primary biliary cirrhosis: A meta-analysis. J Gastroenterol Hepatol 2014;29:706-15.

17. Mo C, Lu Y, Deng $Y$, et al. Lack of association between vitamin $D$ receptor gene Apal, Bsml, and Taql polymorphisms and primary biliary cirrhosis risk: A meta-analysis. Tumour Biol 2014;35:4913-20.

18. Fang F, Wang J, Pan J, et al. Relationship between vitamin D (1,25-dihydroxyvitamin D3) receptor gene polymorphisms and primary biliary cirrhosis risk: A meta-analysis. Genet Mol Res 2015;14:981-8. 